\title{
Design of Key Performance Indicators (KPI) for Sustainable Supply Chain Management (SSCM) Palm Oil Industry in Indonesia
}

\author{
Elisa Kusrini $^{*}{ }^{1}$, Rangga Primadasa ${ }^{1}$ \\ ${ }^{1}$ Department of Industrial Engineering Indonesia Islamic University, J1 Kaliurang Km \\ 14,5Yogyakarta 55584, Indonesia
}

\begin{abstract}
This paper aims to design key performance indicators (KPIs) for evaluating sustainable supply chain management (SSCM) for palm oil processing industry in Indonesia. Supply chain sustainability is the management of environmental, social and economic impacts, and the encouragement of good governance practices, throughout the lifecycle of goods and services. The method in designing KPIs using a triangulation method, ie combining of theory (literature study) with field surveys and validate with the opinion of the expert (expert judgment) as well as compatibility with existing regulations (Indonesian sustainable palm oil / roundtable on sustainable palm oil). There are 29 proposed KPIs for measuring SCM's sustainable palm oil in Indonesia based on literature and expert judgment. In order to obtain a more precise performance, then the importance level of KPI will be measured using Analytic Hierarchy Analysis (AHP) method. According to the preferences of some managers of palm oil using AHP method showed that the economic factor is the most dominant indicator $(62,92 \%)$, followed by environmental $(18,93 \%)$ and social factors $(18,15 \%)$. In subsequent studies, the results of the KPIs will be used to measure the index of sustainability in the palm oil's supply chain industry in Indonesia.
\end{abstract}

\section{Introduction}

Palm oil industry is an important industrial sector for Indonesia since it contribute significant revenue for Indonesia. It can be seen from the total exports of CPO (Crude Palm Oil) for the last three year that remain high. In year 2016, total export reached 25.1 million tons, while in 2015 total export reached 26.40 million tons and in 2014 total export reached 21.76 million tons [1]. The nominal value of CPO exports in 2016 reached 18.1 billion dollars and 2015 reached 18.67 billion dollars [1]. Palm oil industry face many problems and getting increasingly higher. At late 90's palm oil sector started facing criticism due to environmental and social issue such as forest fire and land ownership [2]. Meanwhile, Indonesia's CPO exports to the EU in 2015 reached 4.4 million tons, an

* Corresponding author: elisakusrini@uii.ac.id 
increase of 3 percent compared to 2014 which reached 4.34 million tons [1]. The challenges facing the palm oil industry in Indonesia in 2020 is the European Union plans to apply the rules of obligation 100 percent sustainable supply chain for palm oil-based products. Also, this time there is a tendency of people will spend more money on a product that is a good impact on the environment. To face the challenges mention above, The palm oil industry must improve their sustainability performance throughout their supply chain.

The principle of sustainability can be implemented well, if it is integrated in all the actors in the industry. Hence the sustainable supply chain management (SSCM) is required. SSCM can be used to address issues of socio-environmental and improve the performance of community [3]. Performance measurement systems make an important contribution towards decision making in supply chains [4]. It also helps in organizational change and improvement [5]. Moreover, SSCM performance measurements is required to identify critical indicators that can affect the performance of SSCM in achieving its objectives. Therefore in this research, key performance indicators of SSCM palm oil industry will be identified.

A literature study conducted to determine the indicators that are typically used in the measurement of sustainability. The indicators used are base on study conducted by Veleva et al [6], Faulkneer et al [7], Sparks.D.T [8], Bai\&Sarkis [9], Hall et al [10]. These indicators are then selected based on conformity with the principles, criteria and guidelines of the RSPO (Roundtable on Sustainable Palm Oil) and or ISPO (Sustainable Indonesian Palm Oil). RSPO is an international multi-stakeholder organization established in 2004, adopted the Millennium Development Goals (MDGs) related to 3P (People, Profit, Planet) on the principles and criteria. RSPO is a business initiative whose members voluntarily committed themselves to the RSPO mechanism with the aim to produce and use sustainable palm oil. Principle plantations adhering to the principles of legality prioritize sustainability, environmental and socio-economic feasibility of the long term [11]. In March 2011, the Government of Indonesia through the Ministry of Agriculture launched guidelines for sustainable oil palm plantations Indonesia is often called ISPO. ISPO aims to ensure the implementation of laws and regulations relating to palm oil plantations so that it can be produced sustainable palm oil and support the Indonesian president's commitment to reduce greenhouse gases [12]. While RSPO is voluntarily, ISPO itself is compulsory (mandatory) for plantation companies except small plantation business. This regulation in March 2015 became Certification Systems of Sustainable Palm Oil [13]. This paper proposed a set of Key Performance Indicators (KPIs) to measure the performance of sustainable supply chain management (SSCM) corresponding to the palm oil industry in the three factors of sustainability, namely economic, social and environmental.

\section{Methodology}

There are five stages in identifying KPI. The first step is to identify sustainability KPI based on criteria of ISPO and RSPO. The second step is identifying KPI from literature, and then combine KPI from RSPO/ISPO and literature. The third step is intended to validate KPI from previous step through expert survey. The last step is to weighting KPI using Analytical Hierarchy Process (AHP) based on the preferences of the experts. The results of this research is a set of weighted KPI that can be used to measure sustainability index for the palm oil industry. 


\subsection{Identify KPIs from Principles and Criteria of ISPO/RSPO}

This study begins by identifying sustainability KPI's through reviewing the ISPO and RSPO criteria. Then, KPI of ISPO and RSPO are grouped into three sustainability factors include economic, environmental, and social.

\subsection{Identify KPIs from Literature and Expert Survey}

Reviews of the literature conducted to obtain sustainability KPIs for evaluating sustainable supply chain management (SSCM) palm oil mills, as seen in Table 1. A total of 10 palm oil industry actors/expert (an expert is someone who has knowledge or extensive skills in palm oil more than 7 years) are selected to give opinion regarding the importance level of the KPIs criteria to evaluate the results of KPI from the literature study. The expert is from some positions including : mill manager, head mill assistant, assistant process, quality assurance assistant, SHE assistant, transportation assistant, plantation manager, head plantation assistant, plantation assistant, accounting assistant. The questionnaire using Likert scale with a range of 5 , from 1 (very important) to 5 (very important) is employed as a measuring tool. The average value of the level of importance is presented in Table 1.

The lowest KPI will be removed from the list.

Table 1.KPI from Literature Review and Expert Survey

\begin{tabular}{|l|l|l|l|}
\hline No & \multicolumn{1}{|c|}{ Indicator } & \multicolumn{1}{|c|}{ Literature } & Mean \\
\hline 1 & Work In Process & Faulkneer et.al.[7] & 3.7 \\
\hline 2 & Cost Associated with EHS & $\begin{array}{l}\text { Veleva et.al. [6], } \\
\text { Bai\&Darkis .[9], }\end{array}$ & 3.7 \\
\hline 3 & $\begin{array}{l}\text { Rate of Customer Complaint and } \\
\text { Return }\end{array}$ & Veleva et.al. [6] & 2.8 \\
\hline 4 & Material Usage & $\begin{array}{l}\text { Sparks. D.T [8] Hall et } \\
\text { al [10] }\end{array}$ & 3.6 \\
\hline 5 & Acidification Potential & Veleva et.al. [6] & 3.6 \\
\hline 6 & $\begin{array}{l}\text { Percent Product with Take-back } \\
\text { Policies }\end{array}$ & Veleva et.al. [6] & 3 \\
\hline 7 & Physical Load Index & Faulkneer et.al.[7] & 4.2 \\
\hline 8 & Electrical System Hazard & $\begin{array}{l}\text { Faulkneer et.al.[7], } \\
\text { Bai\&Darkis .[9], }\end{array}$ & 3.7 \\
\hline 9 & Noise Hazard & $\begin{array}{l}\text { Faulkneer et.al.[7], } \\
\text { Bai\&Darkis .[9], }\end{array}$ & 3.7 \\
\hline 10 & $\begin{array}{l}\text { Average Length of Service of } \\
\text { Employees }\end{array}$ & $\begin{array}{l}\text { Veleva et.al [6], Hall } \\
\text { et al [10] }\end{array}$ & 4 \\
\hline 11 & High-Speed Component Hazard & $\begin{array}{l}\text { Faulkneer et.al.[7], } \\
\text { Bai\&Darkis .[9], }\end{array}$ & 3 \\
\hline & & & \\
\hline
\end{tabular}

\subsection{Proposed KPIs base on ISPO/RSPO And Expert Judgment}

The KPI selected from ISPO / RSPO and assessment from industry players and experts are then combined as shown in Table 2. 
Table 2.The Proposed KPI base on ISPO/RSPO and Expert Judgment

\begin{tabular}{|l|l|l|}
\hline No & \multicolumn{1}{|c|}{ Category } & \multicolumn{1}{c|}{ KPI } \\
\hline 1 & & $\begin{array}{l}\text { OER (Extraction), Oil Losses, FFA, } \\
\text { Moisture, \% Breakdown, Lead Time/Plant } \\
\text { Time, Value Added Time, Work In Process, } \\
\text { Cost Associated with EHS }\end{array}$ \\
\hline 2 & Economic & $\begin{array}{l}\text { Water Usage, Energy Usage, Waste } \\
\text { Generated Before Recycled, Global Warming } \\
\text { Potential, BOD, COD, \% Waste Reused, \% } \\
\text { CPO Certified, Material Usage, } \\
\text { Acidification Potential, Percent Product with } \\
\text { Take-back Policies }\end{array}$ \\
\hline 3 & & $\begin{array}{l}\text { Lost Workday and Injury Illness, Hour of } \\
\text { Employee Training, Worker Job satisfaction, } \\
\text { Local Community Hiring, Physical Load } \\
\text { Index, Electrical System Hazard, Noise } \\
\text { Hazard, Average Length of Service of } \\
\text { Employees, High-Speed Component Hazard }\end{array}$ \\
\hline
\end{tabular}

\section{SSCM Model Evaluation Using Analytic Hierarchy Analysis Model (AHP) for Palm Oil Industry}

In this study, SSCM performance evaluation using KPI selected from RSPO/ISPO and actors/expert judgment is proposed. In order to obtain a more precise performance, then the importance level of KPI will be measured using Analytic Hierarchy Analysis (AHP) method. Analytic Hierarchy Process (AHP) was first introduced by Thomas L. Saaty in 1971 and became the most widely method for multiple criteria decision making (MCDM). It is a decision-making approach that is designed to find solutions to complex problem with many criteria into multiple domains. It is also known as an essential tool for practitioners and academics to conduct research in decision making and measure management theory. AHP as a flexible problem-solving methods and systematic tools where can represents elements of a complex problem $[14,15]$.

Cheng.et.al [16] mentioned that AHP has several benefits. First, it helps to breakdown unstructured problems into a hierarchy of rational decision making. Second, it can display a lot of information from experts and decision makers using pair wise comparisons of different groups of individuals. Third, it has calculation procedure to weight the importance level of each element. Fourth, it has consistency measurements to validate the rating given the consistency of experts and decision makers. The following are the stages of development of AHP model for the measurement of sustainable supply chain management (SSCM) of palm oil industry.

\section{Step 1: Creating Hierarchy of Indicators}

The hierarchy of indicators is created from the KPI in the previous stage. The KPI is grouped in to three category, ie, economic, environmental, and social.

\section{Step 2: Weighting the KPIs}


After the hierarchy has been created, the importance of KPIs can be calculated. A questionnaires of pair wise comparisons among indicators is prepared and a total of ten senior managers from palm oil mills were asked to give their preferences on the questionnaires. All managers chosen carefully based on their experience in the palm oil industry. Pair wise comparisons conducted on factor between KPIs. The scale of 1 to 9 (1 = equally, $3=$ moderate, $5=$ strong, $7=$ very strong, $9=$ extreme) is used to rate the preferences of expert. Consistency ratio (CR) is used to check the consistency of the comparison. CR less than 0.1 means that comparison is accepted.

Based on the calculation of CR, It has value between 0.017696 and 0.027408 , which means all pair wise comparisons are consistent because they are on the acceptable range recommended. This indicates that the experts provide consistently in weighting the importance of KPI for sustainable supply chain management palm oil mills. According to the preferences of some managers of palm oil using AHP method showed that the economic factor is the most dominant indicator $(62,92 \%)$, followed by environmental $(18,93 \%)$ and social factors $(18,15 \%)$.

\section{Discussions}

Palm oil mill processing of fresh fruit bunches (FFB) into Crude Palm Oil (CPO) and kernel. This plant also produces waste in the form of empty bunch, palm oil mill effluent (POME), liquid waste and greenhouse gas emissions. The oil industry in general is also facing major challenges in the social such as land ownership conflicts and demands of the welfare of the surrounding community. The application of sustainability have tended to be fragmented and incomplete along the supply chain. Therefore, this study determined indicators to measure the success of the supply chain of palm oil from sustainability's view. There are 29 indicators from KPI selection process based on criteria ISPO and RSPO, literature and judgment from actors/experts. According to the preferences of the manager of palm oil using AHP method showed that the economic factor is the most dominant indicator, followed by environmental and social factors. The most important economic indicators are OER and Oil Losses. The most important indicator in the environmental factor is energy usage, water usage, as well as BOD. The most important indicator of the social factor is the loss of social workday injury and illness and hiring local community. This indicator can be used as guidance for prioritizing action in performance improvement in SSCM palm oil industry.

\section{Conclusions}

There are 29 valid for measurement of SCM sustainable palm oil in Indonesia. KPI's sustainability consists of three categories, namely 9 KPI's economics (OER/extraction), oil losses, FFA, moisture, \% breakdown, lead time/plant time, value added time, work in process, cost associated with EHS), $11 \mathrm{kpi}$ 's environment (water usage, energy usage, waste generated before recycled, global warming potential, $\mathrm{BOD}, \mathrm{COD}, \%$ waste reused, $\%$ CPO certified, material usage, acidification potential, percent product with take-back policies), 9 kpi's social (lost workday and injury illness, hour of employee training, worker job satisfaction, local community hiring, physical load index, electrical system hazard, noise hazard, average length of service of employees, high-speed component hazard). According to the preferences of the manager of palm oil using AHP method showed that the economic factor is the most dominant indicator, followed by social and environmental 
factors. Further research is to measure performance based on KPI's and determine strategies for improvement.

\section{References}

1. Gapki.id, Press release: reflection of palm oil industry 2016 and 2017 outlook, Accessed 2 February (2017)

2. Moyano-Fuentes. J., Martinez-Jurado. P.J, JCP, 85, 134-150,(2014)

3. Kusi-Sarpong. S., Sarkis. J., Wang. X., Int. J. PE, (2015)

4. Kurien G and Qureshi M N, SRE, Vol. 7, pp. 3149-3161 (2012)

5. Tangen S, Analysing the Requirements of Performance Measurement Systems, Measuring Business Excellence, Vol. 9, No. 4, pp. 46-54.,(2005)

6. Veleva. V, Ellenbecker. M., JCP, Vol 9, pp 519-549,(2001)

7. Faulkner. W., Badurdeen. F., Templeton. W., Gullet. David.,Proceedings of International Conference on Industrial Engineering and Operation Management Istanbul, Turkey, July 2-6, (2016)

8. Sparks. D.T., Thesis and Dissertations University of Kentucky UKnowledge, (2014)

9. Bai .C and Sarkis.J, An International Journal 19/3 (2014) 275-291, Emerald Group Publishing Limited [ISSN 1359-8546], [DOI 10.1108/SCM-12-2013-0441],(2014).

10. Hall,J. , Matos,S. and Silvestre,B., IJPR, Vol. 50, No. 5, 1332-1348,(2012)

11. Nedyasari.et.al. 920150 Joint Study of The Same and The Differences ISPO and RSPO Certification, (2015)

12. Ministry of Agriculcure Policy of Republik Indonesia No.11 Year (2015)

13. Principles and Criteria of RSPO, (2006)

14. Saaty TL., Eur JPAM,Vol 1, 122-96, (2008)

15. Chan FTS, Chan HK, Lau HCW, Ip RWL, An International Journal 13 (6): 63661,(2006)

16. Cheng EWL,Li H, Ho DCK..,Analytic Hierarchy Process : A defective tool when used improperly. Measuring Business Excellence Vol 6, 33-37, (2006) 